\title{
Rekomendowane style zarządzania w warunkach ponowoczesności
}

\section{The recommended management in post-modernity}

Streszczenie. W artykule przedstawiono istotę współczesnych stylów zarządzania w kontekście stylu preferowanego przez pracowników, przejawiającego się w pożądanych działaniach i zachowaniach przełożonego.

W perspektywie ponowoczesności skoncentrowanej wokół kapitału ludzkiego, globalizacji i postępu technicznego, sukces organizacji zależy od współpracy zespołu, pobudzonego do działania przez skutecznego menedżera. To jego sposób zarządzania i stosowane metody wyznaczają poziom osiągniętych celów indywidualnych i zespołowych. Studia literaturowe i wyniki badań empirycznych nakreślają oczekiwany styl zarządzania przez pryzmat postawy menedżera.

Słowa kluczowe: style zarządzania, relacje interpersonalne, ponowoczesność, menedżer 


\begin{abstract}
The article presents the essence of modern management styles in the context of the style preferred by employees, manifesting itself in the desired actions and behaviors superior. In the postmodernity centered on human capital, globalization and technological progress, the success of the organization depends on the cooperation of the team, energized into action by an effective manager. It's his way of managing and methods determine the level of achievement of objectives of individual and team. Literature studies and empirical outline the expected style of management through the prism of the attitude of the manager.article aims to analyze the educational grants from budget of local government. Author presented procedures about establish private schools and educational institutions and explained selected concepts about units of education. The article presents selected judgment from SN and NSA in disputes about grants for private schools.
\end{abstract}

Keywords: management styles, interpersonal relationships, post-modernity, manager

\title{
1. Wprowadzenie
}

Współczesne organizacje funkcjonują w warunkach ponowoczesności, która obok racjonalności ekonomicznej koncentruje się wokół globalizacji, postępu technologicznego oraz organizacji wiedzy. Nowe warunki ekonomiczne zmieniają standardowe założenia prowadzenia działalności oraz nadają odmienny kształt relacjom interpersonalnym. Oznaczają umiejętne zarządzanie kapitałem intelektualnym i społecznym, budowanie właściwego zaufania i silnej tożsamości organizacyjnej ${ }^{1}$. Dynamiczna transformacja gospodarcza wpływa na strukturę przedsiębiorstw i ewoluuje postawę kadry menedżerskiej.

\footnotetext{
${ }^{1}$ Przedsiębiorczość i kapitał intelektualny, Praca zbiorowa pod redakcją M. Bratnickiego, J. Strużyny, Wydawnictwo Akademii Ekonomicznej, Katowice 2011, s. 14.
} 
Ponadto, pojawienie się przedstawicieli tzw. pokolenia Y na rynku pracy stawia inne wyzwania w zarządzaniu. Menedżerowie stoją przed koniecznością umiejętnego, międzypokoleniowego kierowania, polegającego na eliminowaniu schematów i uprzedzeń, które wywołując konflikty mogą hamować rozwój zespołu.

Rozwój organizacji wiedzy wykorzystującej umiejętności i kompetencje pracowników, ma szansę sukcesu w nowych uwarunkowaniach, tylko dzięki wspólnemu zaangażowaniu wraz z dzieleniem się wiedzą i doświadczeniem.

W spełnieniu oczekiwań ponowoczesności wskazanymi okazują się style zarządzania realizowane w klimacie pozytywnych relacji interpersonalnych, oparte na wzajemności, zaufaniu i współpracy.

Inspiracją do podjęcia tematu było długoletnie doświadczenie zawodowe autorki na stanowisku menedżera, a także osobiste zainteresowania $\mathrm{w}$ zakresie relacji interpersonalnych poparte wynikami badań empirycznych.

Celem artykułu jest przestawienie na podstawie przeglądu literatury, danych wtórnych oraz wyników własnych badań empirycznych, preferowanego przez pracowników stylu zarządzania, przejawiającego się w pożądanych działaniach i zachowaniach menedżera.

\section{Uwarunkowania ponowoczesności}

Permanentne zmiany gospodarcze wymagają od organizacji nie tylko elastycznego dostosowania się do szybkich zmian, ale przede wszystkim ich wyprzedzania celem uzyskania przewagi konkurencyjnej. „W sprostaniu tym wyzwaniom może pomóc potencjał ludzki, który dzisiaj stał się najważniejszym czynnikiem rozwoju firmy. To dzięki kwalifikacjom i umiejętnościom pracowników, a przede wszystkim ich zaangażowaniu $\mathrm{w}$ realizację zadań firmy organizacja zyskuje na sile" 2 .

2 Z. Janowska, Zarzq̨dzanie zasobami ludzkimi, Polskie Wydawnictwo Ekonomiczne, Warszawa 2010, s. 14 . 
Wzrost zapotrzebowania na profesjonalną wiedzę został spowodowany postępem technologicznym, który wymaga ciągłego aktualizowania i podążania za zmianami. Z kolei dzielenie się informacjami i doświadczeniem stało się niezbędne $\mathrm{z}$ uwagi na funkcjonowanie zróżnicowanych wiekowo zespołów pracowniczych.

Od kilku lat na rynku pracy działają pracownicy pokolenia Y, którzy ceniąc bezpośrednią komunikację i swobodę w wyrażaniu własnego zdania, jawnie przeciwstawiają się stereotypom i standardom. Młodzi pracownicy są otwarci na nowe technologie i doskonale się w nich orientują. Internet, e-maile, media społecznościowe to ich preferowane sposoby wymiany informacji i pozyskiwania partnerów, również biznesowych. Istotą podejmowanych działań przez pokolenie Y jest jasność wyznaczanych celów oraz indywidualnie podejście. Obok młodych pracowników funkcjonują też przedstawiciele tzw. pokolenia X oraz Baby Boomers.

Pracownicy pokolenia Baby Boomers mają zazwyczaj ułożoną i stabilną pozycję w firmie. „Są niezwykle skoncentrowani na pracy i motywowani przez miejsce $\mathrm{w}$ hierarchii, stanowisko oraz prestiż. Potrafią poświęcić długie godziny i okresy pracy, bo swoją tożsamość definiują poprzez osiągnięcia zawodowe” ${ }^{3}$. „Z uwagi na preferowany system wartości często krytykują przedstawicieli młodszych generacji za brak lojalności, zaangażowania i niskiej identyfikacji z zespołem. Posiadany status i osiągnięcia mają dla nich priorytetowe znaczenie"4.

Priorytetem działania przedstawicieli pokolenia $X$ są wymierne korzyści uzyskiwane dzięki przemyślanym transakcjom win- win oraz budowanie osobistej kariery. Doceniają merytoryczne przygotowanie, konkretne ustalenia i dążą do poszukiwania trafnych rozwiązań. Pokolenie $\mathrm{X}$ wyraża przekonanie o słuszności linearnego postępowania i uporządkowanego wypełniania obowiązków.

\footnotetext{
${ }^{3}$ S. Popiel, 2010, s. 74.

${ }^{4}$ E. Podlewska, Innowacje $w$ relacjach interpersonalnych $w$ zespołach pracowniczych, w: Nauka gospodarce, gospodarka nauce, Praca zbiorowa pod redakcją Marleny Piekut, Oficyna Wydawnicza Politechniki Warszawskiej, Warszawa 2014, s. 188.
} 
Potrzeba wymiany doświadczeń w obliczu wielopokoleniowego rynku pracy wskazuje na niezbędne występowanie pozytywnych interakcji między pracownikami. Wzmocnione relacje eliminują luki kompetencyjne i ułatwiają przepływ informacji, przyczyniając się do wzrostu potencjału w firmie. Obecnie pozytywne interakcje oznaczają bowiem nie tylko dobrą komunikację, ale skuteczność, odpowiedzialność i odwagę przy wprowadzaniu zmian.

Wyzwaniem przyszłości jest zatem organizacja inteligentna, która obok klasycznego wykorzystania wiedzy i umiejętności opiera swoje działania na zaufaniu i wspólnym realizowaniu czynności przez pracowników. Nowoczesne myślenie o organizacji potwierdza nurt „Positive Organizational Scholarship - jest to nurt, który eksponuje wartości takie jak wzajemne uznanie i szacunek, współpraca, witalność i spełnienie, które mają służyć dobrej kondycji i zasobności członków społeczności organizacyjnej, które to czynniki stają się warunkami sukcesu współczesnej organizacji”’.

Przejawem ponowoczesności jest również globalizacja, która zrewolucjonizowała sposób biznesowego myślenia. Dzięki zniesieniu barier geograficznych i ekspansji informatycznej rozwinęła się potrzeba budowania światowych kontaktów. „Elektroniczne rynki zmieniły oblicze światowego biznesu, unieważniając pojęcia czasu i odległości. Nastąpił dynamiczny rozwój organizacji i jej zróżnicowanych form w rzeczywistości wirtualnej.

Eksplozja Internetu zmieniła też style komunikowania się. Kontakty osobiste zostały $\mathrm{w}$ zdecydowanej większości zastąpione przez internetowe formy komunikacji, takie jak poczta elektroniczna, platforma e-learningowa, blogi, portale społecznościowe czy systemy konferencyjne audio-video.

Ponowoczesność to nowe realia biznesowe i technologiczne, ale mimo wszechstronnego rozwoju, sukces organizacji postrzega się $\mathrm{w}$ odpowiednim ukształtowaniu kompetencji interpersonalnych.

\footnotetext{
5 Glińska-Neweś A., Kulturowe uwarunkowania zarządzania wiedzq w przedsiębiorstwie, Wydawnictwo Dom Organizatora TNOiK, Toruń 2007, s. 38.
} 


\section{Style zarządzania w nowych realiach gospodarczych}

Styl zarządzania w niniejszym artykule, definiowany jest jako całokształt względnie trwałych wzorów zachowań i sposobów oddziaływania na podległych pracowników w celu przekonania ich do realizacji określonych zadań ${ }^{6}$. Koncentrują się one wokół rodzaju sprawowanej władzy oraz bodźców stosowanych przez przełożonego.

W nowych realiach gospodarczych nie da się wskazać jednego, właściwego stylu dla wszystkich sytuacji. Teraźniejszość eksponuje zróżnicowanie i ewolucję sposobów kierowania, gdyż po pierwsze, na ich bazie powstają ciągle nowe koncepcje, a po drugie, w dużej mierze jest zdeterminowany osobistymi predyspozycjami menedżera. Wymaga też modyfikacji w zależności od czynników kulturowych, społecznych i instytucjonalnych.

Istotą współczesnego stylu zarządzania jest umiejętność jego dostosowania do potrzeb pracowników oraz zmieniających się uwarunkowań wewnętrznych i zewnętrznych.

W kontekście celów artykułu, autorka koncentruje się na wybranych stylach i metodach zarządzania, które bazują na istocie budowania pozytywnych relacji interpersonalnych oraz implikują kształtowanie efektywnego klimatu pracy.

Odwołując się do siatki Blake'a i Mountaina rekomendowanym stylem zarządzania jest styl demokratyczny, zgodnie z którym menedżer na równym poziomie traktuje dbałość o relacje interpersonalne, jak i wymaga wykonywania zadań. Świadomie pozostawia swobodę działania podwładnym, przyznając im prawo do współuczestnictwa w podejmowaniu decyzji.

\footnotetext{
${ }^{6}$ B.R. Kuc, M. Żemigała, Menedżer nowych czasów, Wydawnictwo Helion, Gliwice 2010, s. 36.
} 
Klasyfikacja J.W. Reddina wśród stylów zarządzania XXI wieku zawiera m.in. styl zintegrowany i rozwojowiec. Podejście zintegrowane podkreśla znaczenie indywidualizacji działań pracowników i zachęca do powierzania ambitnych zadań. Menedżer - rozwojowiec deleguje uprawnienia, dba o rozwój pracowników oraz posiada autorytet nieformalny, dzięki czemu jest uważany za menedżera ufnego ${ }^{7}$.

Autorytet nieformalny nie tylko wyznacza poziom zaufania pracowników, ale także wzmacnia wiarygodność, podnosi prestiż oraz daje poparcie dla podejmowanych decyzji. Kwestia autorytetu nieformalnego jest szczególnie istotna dla młodych pracowników, którzy oczekują od przełożonego wykazania się wiedzą, umiejętnościami i innymi kompetencjami niezbędnymi na stanowisku pracy. Pojęcie autorytetu niewiele ma dla nich wspólnego z bezwzględnym poszanowaniem pozycji czy stanowiska pracy, co jest bezsprzeczne dla pokolenia $\mathrm{BB}$, wykazującego oddanie wobec przełożonego $\mathrm{z}$ racji pełnionej przez niego funkcji.

Kształtowanie autorytetu nieformalnego umożliwia stosowanie stylu zarządzania jakością pracy, polegającego na docenieniu poprawnie wykonanych zadań, a z drugiej strony na wskazaniu konkretnych obszarów do poprawy wraz z propozycjami doskonalenia działań. Menedżer wspiera pracownika, dzieląc się własnym doświadczeniem i wiedzą. Podkreśla jego mocne strony i eliminuje słabe. Daje podłoże do wzrostu efektywności, a jednocześnie potwierdza osobiste kompetencje. Właściwymi narzędziami stylu zarządzania jakością pracy są konstruktywna informacja zwrotna, okresowa ocena pracownicza, indywidualne spotkania i spotkania ad hoc, gdy menedżer lub podwładny uznają, że są one w danej chwili konieczne.

„Mimo, że skuteczne zarządzanie jakością pracy może wywrzeć olbrzymi wpływ na przyszły i teraźniejszy sukces firmy nie zawsze bywa wysoko cenione. Chociaż, to dzięki niemu menedżero-

\footnotetext{
${ }^{7}$ A. Wajda, Podstawy nauk o zarządzaniu, Wydawnictwo Difin, Warszawa 2004, s. 39-41.
} 
wie rozwijają talenty, osiągają wysoką wydajność i rozwiązują problemy, wiele przedsiębiorstw kładzie większy nacisk na liczby, normy i wyniki ${ }^{8}$. Wyznaczając indywidualne cele realizowania obowiązków kierowniczych menedżerowie nie dostrzegają kształtowania klimatu pracy jako jednego z głównych zadań. $\mathrm{O}$ ile pokolenie BB i pokolenie $\mathrm{X}$ potrafią zrozumieć postawę menedżera, to młoda generacja, nie odczuwając uznania odejdzie z pracy.

G.T. Hunt podaje, że optymalnym dla współczesnych warunków jest styl kierowania przez komunikację, obejmujący obopólne interakcje między przełożonym a podwładnymi z wykorzystaniem wszystkich kanałów komunikacyjnych ${ }^{9}$. Styl ten opiera na bezpośrednich relacjach kadry kierowniczej z pracownikami stanowiąc czynnik sukcesu przedsiębiorstwa ${ }^{10}$. Sprawne komunikowanie się tworzy skonsolidowane otoczenie zarządzania. Przenika przez wszystkie jego kluczowe funkcje, determinuje funkcjonowanie zespołów pracowniczych,

a w konsekwencji prowadzi do pożądanych rezultatów pracy. Istotą komunikacji kierowniczej jest jasne artykułowanie celów, planów, wzbudzanie inicjatywy pracowników oraz integracja działań zmierzających do realizacji wspólnych przedsięwzięć ${ }^{11}$.

P.F. Drucker stwierdza, że zarządzanie ludźmi w XXI wieku wymaga kształtowania wzajemnej współpracy tak, aby właściwie zagospodarować ich zdolności i umiejętności oraz neutralizować zachowania, które obniżają efektywność organizacji12. Zróżnicowane

\footnotetext{
8 J. Leary-Joyce J, Inspirujący menedżer, Oficyna, Warszawa 2010, s.162.

9 Cz. Sikorski, Zachowania ludzi w organizacji, Wydawnictwo Naukowe PWN, Warszawa 2002, s. 93.

${ }^{10}$ R. IIies, T.Judge, On The heritability of job satisfaction: The mediating role of personality, „The Journal of Applied.

Psychology", Nr 88(4), s. 32-33.

11 S. Stańczyk, Zarządzanie przez komunikowanie w: Zarzq̨dzanie przedsiębiorstwem przyszłości. Koncepcje, modele, metody.

Pod redakcją K. Perechudy, Agencja Wydawnicza Placet, Warszawa 2000, s. 174.

12 S. Stańczyk, op. cit., 174.
} 
poglądy w wielopokoleniowych zespołach, może być źródłem konfliktów i ograniczać współdziałanie.

Współczesne zarządzanie zmierza do spłaszczania relacji między przełożonymi a podwładnymi, ewoluujących z form patriarchalnych do form partnerskich. Konsekwencją osłabienia zależności hierarchicznych jest wymóg wyzwolenia samodzielności pracowników, z uwagi na konieczność szybkiej reakcji na pojawiające się problemy. Dla pracowników pokolenia Y wymóg ten pozwala spełnić potrzebę indywidualności i umożliwia wzrost poczucia odpowiedzialności. Powierzenie samodzielnych zadań sprzyja samorealizacji, a zaangażowanie ich we wspólne projekty kreuje klimat współpracy, w którym następuje wszechstronna wymiana myśli, poglądów i opinii. Dzięki konsultacjom, rozmowom oraz zgłaszaniu pomysłów, wzrasta udział pracowników w decyzjach zespołu i oznacza współuczestnictwo $\mathrm{w}$ procesie zarządzania. W literaturze przedmiotu powyższe działania nazywane są zarządzaniem przez partycypację.

Zarządzanie przez partycypację obejmuje jedną z najistotniejszych i jednocześnie niełatwą do zastosowania kompetencję w kierowaniu ludźmi - przekazywanie decyzyjności. Proces ten może przebiegać w oparciu o:

- współdecydowanie o procesie pracy i wywieranie wpływu na kształtowanie otoczenia (partycypacja bezpośrednia)

- czynny udział reprezentacji zespołu podczas wyboru sposobów realizacji planów czy doboru wykorzystywanych instrumentów (partycypacja pośrednia).

„D. McGregor podkreśla, że w pewnych warunkach partycypacja stwarza ludziom możliwości wpływania na decyzje, które ich dotyczą. R. Likert z kolei opisuje partycypację jako proces podejmowania decyzji - są weń zaangażowani wszyscy podwładni w zespole, których 
decyzja dotyczy13". Włączanie pracowników do procesu podejmowania decyzji oraz współuczestnictwa w sprawach zespołu jest wyrazem zaufania i umacnia wzajemne więzi interpersonalne .

Elastyczność stylów zarządzania to wskazana umiejętność nie tylko w związku z sytuacją wielopokoleniowej kadry, ale także w obliczu ciągłych zmian gospodarczych.

Brak realizacji skutecznego procesu kierowania prowadzi do luk kompetencyjnych pracowników i stagnacji, co obniża ich wartość na rynku pracy oraz efektywność organizacji.

\section{Style zarządzania w świetle badań empirycznych}

Autorka przeprowadziła empiryczne badanie jakościowe w 2016 roku na terenie województwa kujawsko-pomorskiego wśród pracowników trzech przedsiębiorstw o profilu produkcyjno - usługowym. Celem badania było zidentyfikowanie potencjalnego i faktycznego stanu $\mathrm{w}$ obszarze pozytywnych relacji interpersonalnych $\mathrm{w}$ zespołach pracowniczych.

Badane organizacje zatrudniają łącznie 226 pracowników, w tym 32 menedżerów. Proces badawczy obejmował badania za pomocą kwestionariuszy ankietowych, wywiadów indywidualnych, nieskategoryzowanych z kadrą kierowniczą i pracownikami oraz zogniskowanych wywiadów grupowych z pracownikami.

W badaniu ankietowym wzięło udział 158 podwładnych oraz 27 menedżerów, co stanowiło 81\% ogółu zatrudnionych pracowników szeregowych oraz 84\% menedżerów.

Zadaniem respondentów uczestniczących w badaniu ankietowym było dokonanie przy użyciu skali $0-100 \%$ m.in. poziomu istotności narzędzi preferowanych w procesie budowania relacji interperso-

\footnotetext{
13 B. Kożusznik ,Zachowania człowieka w organizacji, Polskie Wydawnictwo Ekonomiczne,
} Warszawa 2007, s.148. 
nalnych, oczekiwanych cech w postawie i zachowaniu przełożonego, hierarchii celów realizowania obowiązków kierowniczych przez przełożonych oraz czynników sprzyjających kształtowaniu pozytywnych interakcji.

Celem wywiadów zarówno z menedżerami, jak i z pracownikami było uzyskanie informacji o stanie faktycznym występującym $\mathrm{w}$ zespole. Rozmowy z przełożonymi pozwoliły pozyskać dane, głównie $\mathrm{w}$ zakresie stosowanych w praktyce narzędzi budowania relacji oraz sposobach rozwiązywania sytuacji konfliktowych. Wywiady z pracownikami były wyrazem opinii, m.in. o najważniejszych czynnikach w procesie kształtowania pozytywnej atmosfery, a także umożliwiły określenie pożądanego stylu zarządzania przełożonego przez pryzmat posiadanych przez niego cech i przejawianych zachowań.

Wywiady zostały zrealizowane podczas osobistych kontaktów i zarejestrowane w formie pisemnej. Autorka zwracała szczególną uwagę na uzasadnianie wypowiadanych kwestii, dzięki czemu miała możliwość zdiagnozować okoliczności występujących sytuacji oraz zidentyfikować podłoże prezentowanych postaw.

Na potrzeby artykułu wykorzystana informacje pozyskane $\mathrm{z}$ wywiadów przeprowadzonych z pracownikami zarówno $\mathrm{w}$ formie indywidualnej, jak i grupowej. Łącznie zrealizowano 38 wywiadów (26 indywidualnych i 8 grupowych), w których uczestniczyło 122 pracowników, co stanowiło $77 \%$ ankietowanych pracowników, a $63 \%$ zatrudnionych.

Uzyskane wyniki podczas procesu badawczego, a także poznane odczucia i spostrzeżenia w zakresie stanu istniejącego w zespole dały podstawę do wnioskowania i rekomendacji. 


\subsection{Wyniki badań}

Nadrzędną kwestią badawczą artykułu było zdiagnozowanie preferowanego przez pracowników stylu zarządzania, zidentyfikowanego na podstawie pożądanych cech, działań i zachowań przełożonego.

Wyniki przeprowadzonych wywiadów z pracownikami pozwalają stwierdzić, że postawy i zachowania przełożonego, składające się na prezentowany styl zarządzania oznaczają, że menedżer:

- Posiada wysokie kompetencje merytoryczne i branżową wiedzę.

- Dla pracowników pokolenia Y w $80 \%$ istotne jest, żeby wykazywał się profesjonalizmem w praktycznym działaniu, angażował w pracę zespołu i wskazywał pomocne rozwiązania. Dopiero wówczas jego wymagania spotykają się z pełną akceptacją pracowników.

- Wymagania menedżera muszą być osadzone w realnych uwarunkowaniach.

- Dla pracowników pokolenia Y, menedżer ma być inspiracją do pracy i umożliwiać samodzielność na stanowisku pracy.

- Jasno wyznacza cele i konkretnie formułuje zadania.

- Potrafi stymulować relacje w zespole w kierunku relacji partnerskich, nie koleżeńskich.

- Posiada umiejętności interpersonalne, w tym zdolność efektywnej komunikacji

i budowania porozumienia.

- Wykazuje "ludzką twarz" - jest wyrozumiały wobec błędów, empatyczny, szczery.

- W zakresie stosowanych narzędzi budowania relacji stosuje przede wszystkim pochwałę, mówi „dziękuję” i docenia indywidualne zaangażowanie.

- Jest otwarty na argumenty i szanuje odmienne zdanie. Wywiady pokazały, że w rzeczywistych warunkach menedżerowie są otwarci na odmienne zdanie pracowników i chętnie słuchają ich argumentów, jednak w ostateczności w 90\% podejmują indywidualną decyzję nie 
uwzględniając sugestii ani zdania pracowników. Zdarza się też, że nie potrafią przyznać się też do błędów.

- Odpowiednio wykorzystuje konstruktywną informację zwrotną, gdyż stan faktyczny pokazuje, że w $75 \%$ taka informacja od menedżera nie występuje. W pozostałych sytuacjach informacja o jakości czy poziomie wykonania zadania przybiera formę raportu zero - jedynkowego, tj. dobrze-źle, bez wskazania mocnych stron, czy obszarów do poprawy.

Wyniki uzyskane z wywiadów pozwalają zarekomendować, aby menedżerowie podczas codziennej pracy zwrócili uwagę na uzasadnianie celowości wykonywania zadań. Da to odpowiedź pracownikom na pytania: Po co to mam zrobić? Czemu to ma służyć?, co pozwoli wyeliminować niezrozumienie przy efekcie końcowym. Warto również przeszkolić menedżerów w zakresie istoty konstruktywnej informacji zwrotnej oraz umiejętności podejmowania optymalnych decyzji w zespole.

\section{Podsumowanie}

Artykuł miał na celu przedstawienie preferowanego przez pracowników stylu zarządzania, przejawiającego się w pożądanych działaniach i zachowaniach menedżera.

Postępująca ewolucja gospodarcza wskazuje, że zmiany zachowań zarówno wśród pracowników, jak i menedżerów są nieuniknione.

W generalnej konkluzji z przeprowadzonych rozważań należy zdaniem autorki, zaznaczyć wagę doskonalenia kompetencji w zakresie umiejętności interpersonalnyci komunikacyjnych menedżerów. Warto też wskazać konstruktywną informację zwrotną, jako narzędzie dające wymierne korzyści dla organizacji. Autorka rekomenduje także weryfikację kierunku działań menedżera, zarówno w odniesieniu do zakresu podnoszonych kwalifikacji, jak również wobec celów realizowania obowiązków kierowniczych. Organizacje funkcjonujące 
z sukcesem w nowych uwarunkowaniach, odnajdują wśród priorytetowych celów miejsce dla relacji interpersonalnych, dostrzegając $w$ nich źródło wzbudzania poczucia odpowiedzialności w pracownikach i zaangażowania oraz prowadzące do efektywnej współpracy.

Przedstawiona $\mathrm{w}$ artykule tematyka $\mathrm{w}$ dalszym ciągu wzbudza zainteresowanie autorki, dlatego będzie obszarem do prowadzenia pogłębionych badań w zakresie relacji interpersonalnych.

\section{Bibliografia}

Drucker P.F., Myśli przewodnie Druckera, MT Biznes, Warszawa 2002.

Glińska-Neweś A., Kulturowe uwarunkowania zarzqdzania wiedzq w przedsiębiorstwie, Wydawnictwo Dom Organizatora TNOiK, Toruń 2007.

Ilies R., Judge T., On The heritability of job satisfaction: The mediating role of personality, „The Journal of Applied Psychology”, Nr 88(4).

Janowska Z., Zarzq̨dzanie zasobami ludzkimi, Polskie Wydawnictwo Ekonomiczne, Warszawa 2010.

Kożusznik B., Zachowania człowieka w organizacji, Polskie Wydawnictwo Ekonomiczne, Warszawa 2007.

Kuc B.R, M. Żemigała M., Menedżer nowych czasów, Wydawnictwo Helion, Gliwice 2010.

Leary-Joyce J, Inspirujący menedżer, Oficyna, Warszawa 2010.

Podlewska E., Innowacje $w$ relacjach interpersonalnych $w$ zespołach pracowniczych, w: Nauka gospodarce, gospodarka nauce, Praca zbiorowa pod redakcją Marleny Piekut, Oficyna Wydawnicza Politechniki Warszawskiej, Warszawa 2014.

Przedsiębiorczość i kapitał intelektualny, Praca zbiorowa pod redakcją M. Bratnickiego, J. Strużyny, Wydawnictwo Akademii Ekonomicznej, Katowice 2011. 
Sikorski Cz.,, Zachowania ludzi w organizacji, Wydawnictwo Naukowe PWN, Warszawa 2002.

Stańczyk S., Zarzq̨dzanie przez komunikowanie w: Zarządzanie przedsiębiorstwem przyszłości. Koncepcje, modele, metody. Pod redakcją K. Perechudy, Agencja Wydawnicza Placet, Warszawa 2010.

Wajda A., Podstawy nauk o zarządzaniu, Wydawnictwo Difin, Warszawa 2004. 